\title{
PENGELOLAAN KEUANGAN KELUARGA DALAM MEMBANGUN KEMANDIRIAN EKONOMI DI ERA REVOLUSI INDUSTRI 4.0
}

\author{
Wijaya Triwacananingrum \\ Universitas Pelita Harapan \\ wijaya.tri@uph.edu
}

\begin{abstract}
Abstrak
Kesenjangan ekonomi di suatu negara merupakan permasalahan global yang terjadi di berbagai negara di belahan dunia ini, berbagai upaya dilakukan oleh banyak negara untuk mempersempit kesenjangan dengan memberi kesempatan-kesempatan yang luas bagi masyarakat ekonomi bawah untuk berusaha meningkatkan kesejahteraannya. Kemandirian ekonomi suatu bangsa akan dengan cepat dicapai jika dimulai dari tercapainya kemandirian ekonomi di seluruh lapisan masyarakat. Kemandirian ekonomi dari yang paling sederhana dimulai dari ekonomi keluarga, hal ini semakin diperlukan apalagi di era revolusi industri 4.0 yang mengharuskan setiap orang menyesuaikan diri dengan perubahan untuk tetap bertahan hidup. Dalam rangka memberikan respon permasalahan diatas, dalam membangun ekonomi keluarga, disadari tidak terlepas dari peran ibu dalam mengelola keuangan keluarga, untuk itu perlu digalakkan pelatihan-seminar tentang bagaimana mengelola keuangan keluarga di komunitas-komunitas perempuan, diantaranya yang telah dilakukan di perkumpulan ibu-ibu Gereja Kristen Indonesia (GKI) Serpong dan komunitas wanita Yayasan Anak Panah Indonesia. Melalui seminar ini ibu-ibu diberikan gambaran keadaan ekonomi saat ini, hal ini dilakukan untuk membangun kesadaran pentingnya mengelola keuangan keluarga, kemudian dijelaskan tahap-tahap yang harus dilakukan dalam pengelolaan keuangan keluarga, kemudian diberikan gambaran dan contoh bagaimana mengembangkan pendapatan keuangan keluarga, dan sebagai evaluasi kami melakukan tanya jawab dan diskusi tentang topik yang berhubungan dengan bagaimana mengelola keuangan keluarga.
\end{abstract}

Kata kunci: Keuangan keluarga, perempuan, kemandirian ekonomi, era revolusi industri 4.0

\section{PENDAHULUAN}

Permasalahan global yang ada di negara berkembang biasanya tentang kesenjangan ekonomi, bahkan di berbagai negara di belahan dunia ini, berbagai upaya dilakukan oleh banyak negara untuk menekan kesenjangan dengan membuka peluang-peluang yang luas bagi masyarakat ekonomi lemah untuk berusaha meningkatkan pendapatan yang pada akhirnya dapat meningkatkan kesejahteraannya. Kemandirian ekonomi suatu bangsa mau tidak mau harus dimulai dari membereskan tercapainya kemandirian ekonomi terkecil di seluruh lapisan masyarakat. Kemandirian ekonomi yang paling kecil dimulai dari ekonomi keluarga, kesadaran pentingnya pengelolaan keuangan keluarga dengan baik semakin diperlukan apalagi di era revolusi industri 4.0 yang mengharuskan setiap orang menyesuaikan diri dengan perubahan untuk dapat mengimbangi cepatnya perubahan tersebut, yang akan berdampak pada sektor ekonomi global, dan pada akhirnya pula akan berdampak pada ekonomi keluarga. Dalam bukunya " The Fourt Industrial

$$
\text { Ekonomi, Sosial, dan Budaya }
$$


Revolution” Prof. Klaus Schwab (2017) menyatakan bahwa revolusi industry generasi keempat ini memiliki skala, ruang lingkup dan kompleksitas yang lebih luas dibanding dengan revolusi-revolusi industry sebelumnya, bahkan mendorong system otomatisasi dan integrasi pada semua proses aktivitas manusia dan teknologi. Hal ini cepat atau lambat akan menciptakan situasi pergeseran dari tenaga kerja manusia kearah digitalisasi, Berbicara tentang ekonomi keluarga maka tidak lepas dari peran perempuan dalam keluarga. Peran ganda perempuan sebagai ibu yang bertanggung jawab terhadap urusan rumah tangga dan sekaligus ikut bertanggung jawab akan pekerjaan (Dwi Edi Wibowo, 2011). Hal yang sangat kental untuk kultur perempuan di Indonesia khususnya yang cenderung memegang kodratnya sebagai perempuan menjadi ibu rumah tangga, mengurus anak.

Perempuan sebagai bagian dari peradaban dunia. Seorang perempuan berkualitas adalah perempuan yang mampu menempatkan dirinya pada dua peran penting yaiyu sebagai seorang ibu untuk mendidik anak sebagai generasi masa depan sekaligus sebagai perempuan yang mampu berperan di ranah publik di era revolusi industri 4.0 saat ini (Yohana Yembise, 2018) dan Menteri Pemberdayaan Perempuan dan Perlindungan Anak (PPPA) ini juga memaparkan bahwa dibutuhkan peran Perguruan Tinggi diantaranya dalam menggali potensi kaum perempuan yang mampu menghadapi persaingan di era revolusi industri 4.0 dan perempuan juga harus bisa menjadi pendididk yang dapat mengajar dan membina anak-anak nya sebagai generasi penerus bangsa di era revolusi industri 4.0 yang memiliki tantangan tersendiri sehingga sebagai ibu juga harus mau membuka diri, dan mau terus menerus belajar mengikuti setiap perubahan-perubahan jaman yang semestinya diikuti dengan perubahan perilaku,karakter dan sikap manusia yang hidup di era ini. Demikian juga isi dari program Sustainable Development Goals (SDGs) yang menekankan peningkatan penggunaan teknologi informasi dan komunikasi untuk pemberdayaan perempuan (Gaib \& Dkk, 2017)
Pengelolaan keuangan rumah tangga merupakan salah satu aspek penting yang perlu dipahami oleh ibu rumah tangga. Mengatur dan mengelola keuangan bahkan seringkali menjadi pokok masalah dalam keluarga, diperlukan pemahaman yang baik bagaimana merencanakan keuangan keluarga, bagaimana cara mencatatnya dan bagaimana pula mengevaluasi keuangan keluarga ini.

Sesuai dengan kebutuhan para ibu tersebut dan sesuai dengan bidang ilmu akuntansi dari peneliti sebagai pengajar di Program Studi Akuntansi Fakultas Ekonomi dan Bisnis Universitas Pelita Harapan maka peneliti diminta kelompok ibu-ibu yang tergabung di kaum wanita Gereja Kristen Indonesia (GKI) Serpong yang berlokasi di Griya Anugerah, Gading Serpong untuk mengadakan kegiatan Pengabdian Kepada Masyarakat dengan memberikan seminar penyuluhan tentang bagaimana mengelola keuangan keluarga, yang dapat memberikan bekal pengetahuan dan contoh-contoh praktek pengelolaan keuangan. Dengan menggali potensi perempuan diharapkan peserta mampu mengelola pendapatan keluarga, dan akhirnya mampu meningkatkan pendapatan keluarga dengan membuat usaha kecil misalnya, sehingga kemandirian perempuan dapat ditingkatkan dan diharapkan pula kemandirian keuangan keluarga juga tercapai, yang pada akhirnya kemandiri ekonomi di di area yang lebih luas lagi dapat dicapai.

\section{METODE}

Kegiatan Pengabdian Kepada Masyarakat ini menggunakan metode penyampaian informasi melalui seminar. Seminar dibagi menjadi empat sesi yaitu pemaparan materi, pembahasan contoh-contoh perhitungan yang melibatkan peserta, diskusi tentang peluang meningkatkan pendapatan keluarga, dan terakhir tanya jawab. Pada sesi pertama peserta diberikan materi tentang konsep-konsep pengelolaan keuangan, pada sesi kedua peserta diberikan contohcontoh dalam bentuk perhitungan-perhitungan dan setelah itu peserta diberikan soal pada selembar kertas untuk dicoba menghitung sesuai konsep yang

$$
\text { Ekonomi, Sosial, dan Budaya }
$$

1510 
telah diberikan sebelumnya, pada sesi yang ketiga, peserta diajak untuk berdiskusi tentang peluangpeluang bagaimana mengembangkan pengelolaan keuangan keluarga untuk meningkatkan pendapatan keluarga, dan pada sesi terakhir peserta dipersilakan untuk bertanya dan peneliti akan menjawabnya. Dalam penyampaian informasi materi dan menjawab pertanyaan-pertanyaan dari peserta, pembicara yang memiliki riwayat pendidikan akuntansi dan pengalaman sebagai pengajar dan praktisi di bidang akuntansi akan menjadi suatu credibility proof yang mana sangat sesuai dengan tema yang diangkat tentang pengelolaan keuangan.

Pemaparan materi juga menggunakan alat bantu power point yang telah disiapkan sebelumnya, untuk dapat mendukung dan memudahkan pembicara memvisualisasikan informasi dengan lebih menarik (DeVito, 2015).

\section{HASIL DAN PEMBAHASAN}

\section{Hasil}

Persiapan pelaksanaan kegiatan PkM dilakukan dua bulan sebelum kegiatan ini dilaksanakan, pada awal persiapan dilakukan komunikasi secara intens dengan pihak gereja untuk mendiskusikan tujuan pengabdian tersebut dan mengetahui keberadaan serta kebutuhan calon peserta seminar agar kegiatan tersebut tepat sasaran dan optimal. Setelah komunikasi terlaksana dengan baik proposal PkM dibuat dan diajukan ke Lembaga Penelitian dan Pengabdian Masyarakat (LPPM) Universitas Pelita Harapan (UPH)

Pelaksanaan Kegiatan dimulai dengan registrasi kehadiran, pujian dan doa dan acara pembukaan tepat pukul 10.00 diawali dengan kata sambutan dari pihak UPH dan dari Ketua kaum wanita GKI Gading Serpong untuk menandai dimulainya kegiatan.

Kegiatan seminar dengan durasi waktu 3 jam dibagi menjadi empat sesi : 1) Pada sesi pertama peserta diberikan materi tentang konsep-konsep pengelolaan keuangan, hal ini diawali dengan konsep uang menurut pandangan Alkitab yang mana uang mencerminkan keberadaan kita karena mempresentasikan waktu, talenta, kemampuan dan kerja keras kita (Alkitab, Matius $6: 21$ ); pembahasan dilanjutkan dengan memaparkan kondisi ekonomi Indonesia saat ini di era revolusi industry 4.0 dan dampak di perekonomian global yang mengalami pertumbuhan ekonomi yang melambat dan Indonesia juga mengalami masalah yang sama, kemiskinan, ketimpangan dan kesenjangan ekonomi dan pengangguran masih menjadi isu yang serius dan juga terbatasnya peningkatan pendapatan dibanding peningkatan kebutuhan (Hadad, M dan Mattuchah, 2015); paparan berikutnya adalah pemahaman tentang dasar umum mengelola keuangan yang terdiri dari perencanaan keuangan, pengendalian keuangan dan pengambilan keputusan tentang keuangan, kemudian peserta juga diajak mengenal tentang sumber-sumber penghasilan keluarga misalnya gaji, hasil usaha, hibah dan lainnya. Pemaparan berikutnya tentang bagaimana cara mengalokasikan penghasilan apakah untuk pemenuhan keinginan, pelunasan hutang atau untuk pemenuhan kebutuhan. Dan pemaparan selanjutnya bagaimana membuat skala prioritas dalam pengelolaan keuangan yang dapat dimulai dari pemenuhan kebutuhan, menabung dan investasi (Kieso, Jerry J.Weygandt \& Paul D. Kimmel. 2019) 2) Pada sesi kedua peserta diberikan contoh-contoh dalam bentuk perhitungan-perhitungan sederhana serta konsep pendapatan dan pengeluaran dalam pengelolaan keuangan untuk memudahkan pemahaman, setelah itu peserta diberikan soal sederhana pula pada untuk mencoba mencatat dan menghitung keuangan keluarga sesuai konsep yang telah diberikan sebelumnya, 3) Pada sesi yang ketiga, peserta diajak untuk berdiskusi tentang peluangpeluang bagaimana mengembangkan pengelolaan keuangan keluarga untuk meningkatkan pendapatan keluarga, misalnya dengan membuat usaha kecil sesuai dengan minat dan talenta dari peserta masingmasing dan dengan mempertimbangkan pula tentang kesempatan atau peluang yang ada di sekitar lingkungannya. Pada sesi ini peserta diberikan

Ekonomi, Sosial, dan Budaya

1511 
gambaran tentang konsep pemisahan modal usaha dari uang pribadi dan bagaimana pentingnya kedisiplinan diperlukan dalam mengelola keuangan keluarga ini (Kusuma, Indra Wijaya. 2013). 4) pada sesi terakhir peserta dipersilakan untuk bertanya dan peneliti akan menjawabnya. Pada sesi ini peserta yang belum pernah memiliki usaha sangat antusias diantaranya menanyakan bagaimana caranya membulatkan tekat untuk memulai suatu usaha agar dapat membantu meningkatkan pendapatan keluarga, sedangkan para peserta yang telah memulai usahanya banyak menanyakan bagaimana untuk mempertahankan pendapatan usahanya tersebut bahkan bagaimana caranya meningkatkan pendapatan dari usanya tersebut serta bagaimana caranya mengevaluasi pendapatan usahanya tersebut.

Setelah empat sesi pemaparan kegiatan dilaksanakan maka dilakukan penyerahan plakat dari UPH kepada Pengurus kaum wanita GKI Gading Serpong disertai acara foto bersama serta acara ditutup dengan makan siang bersama.

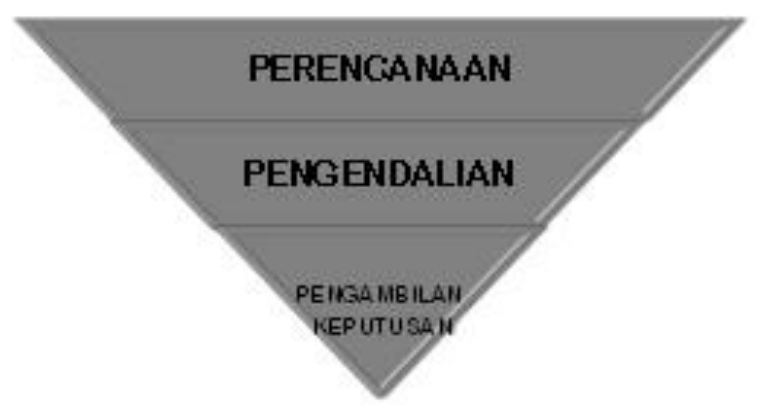

Gambar 1. Dasar Umum Mengelola Keuangan



Gambar 2. Pengalokasian Penghasilan

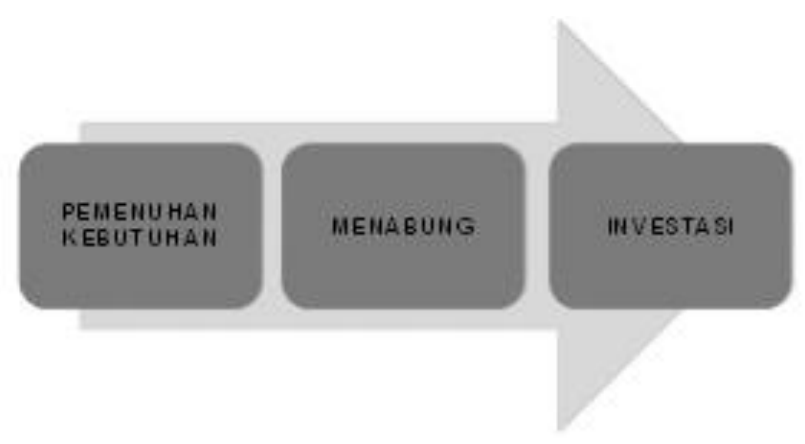

Gambar 3. Membuat Skala Prioritas

\section{Pembahasan}

Hal yang paling menarik selain meningkatnya pemahaman para perempuan tentang pentingnya kesadaran dalam mengelola keuangan keluarga adalah dari diskusi dan tanya jawab tersebut sesungguhnya sudah terjadi pembelajaran dan sharing diantara para peserta yang berjumlah 52 perempuan tersebut, serta dari acara seminar ini para perempuan semakin menyadari pentingnya peran perempuan dalam kebahagiaan keluarganya yang mana perempuan sebagai isteri merupakan tulang rusuk yang diciptakan Tuhan sebagai penolong suami. Dan kembali ke rumah untuk mengelola keuangan keluarga dengan bijak.

\section{Keberlanjutan PkM}

Kegiatan pengabdian kepada masyarakat dengan tema pengelolaan keuangan keluarga ini adalah program yang berkesinambungan yang dilakukan oleh peneliti dalam rangka melaksanakan peran 
keberadaan perguruan tinggi yang memberikan dampak kepada masyarakat.

\section{SIMPULAN DAN SARAN}

\section{Simpulan}

Simpulan yang dapat diambil dari kegiatan Pengabdian Kepada Masyarakat ini adalah peserta para perempuan ibu rumah tangga yang secara kondrat bertanggung jawab dalam mengelola rumah tangga, mendidik putra putri di era revolusi industry 4.0, sangatlah antusias dalam menanggapi penyuluhan tentang pengelolaan keuangan keluarga, apalagi saat pemaparan tentang peluang-peluang bagi perempuan dalam ikut meningkatkan pendapatan keluarga, hal ini akan menjadi tantangan dari para perempuan dalam melakukan peranperannya. Pertanyaan-pertanyaan yang diajukan pada sesi keempat menggambarkan betapa para perempuan ini sesungguhnya sangat tergerak hatinya untuk dapat memperbaiki dan membangun keuangan keluarganya.

\section{Saran}

Saran dari kegiatan pengabdian ini adalah alangkah lebih bermanfaat apabila penyuluhan tentang pengelolaan keuangan keluarga dilakukan secara berseri, tahap demi tahap pengelolaan keuangan dengan bijak yang dilakukan di pantau sehingga terjadi pendampingan apabila para perempuan ini mulai ingin membangun usahanya, dan juga dilakukan pendampingan pula buat mereka yang telah memulai usahanya untuk menjadi lebih berkembang lagi, Dengan cara demikian tujuan yang diharapkan akan benar-benar terealisasi bahwa keberadaan perguruan tinggi benar-benar membawa dampak kepada masyarakat.

\section{UCAPAN TERIMA KASIH}

Terima kasih kepada Universitas Pelita Harapan (UPH) yang memberikan dukungan dan kesempatan atas terlaksananya kegiatan Pengabdian kepada
Masyarakat dengan tema utama "Bijak dalam Mengelola Keuangan" dan paper ini dapat dipresentasikan dalam acara Konferensi Nasional PKM-CSR 2019. Terima kasih juga untuk Kaum wanita jemaat GKI Gading Serpong yang telah memberikan kesempatan saya menjadi nara sumber pada seminar penyuluhan ini.

\section{REFERENSI}

Alkitab. (2004). Jakarta. Lembaga Alkitab Indonesia.

DeVito, J. A. (2015). Human Communication. $13^{\text {th }}$ ed. Boston. MA : Pearson

Gaib, H., \& Dkk. (2017). Profil Perempuan Indonesia 2017. (Santosa Didiek, Ed.). Jakarta: KP3A

Hadad, M. \& Mattuchah, I. (2015). Sustainable Financing: Industri Jasa Keuangan dalam Pembiayaan Berkelanjutan. Gramedia Group: PT. Elex Media Komputindo.

Kieso, Jerry J.Weygandt \& Paul D. Kimmel. (2019) Financial Accounting. $4^{\text {th }}$ Edition. Wiley

Kusuma, Indra Wijaya. (2013). Antara Hasrat Bisnis dan Cinta. Aswaja Pressindo.

Rahmawati, D. Nu., \& Lukitasari, I. (2017). Pembangunan Manusia Berbasis Gender 2017. (S. B. Widoyono \& Dkk, Eds). Jakarta: KP3A

Schwab, K. (2017). The Fourth Industrial Revolution. Crown Business Press

Wibowo, Dwi Edi. Peran Ganda Perempuan dan Kesetaraan Gender. Muwazah, Vol. 3, 01 Juli 2011.

Yembise, Yohana. Daya Saing Perempuan Di Era Revolusi Industry 4.0. Siaran Pers Nomor: B-049 Set Rokum MP 01-04-2018. Kementerian Pemberdayaan Perempuan dan

Ekonomi, Sosial, dan Budaya

1513 
Perlindungan Anak (PPPA) Republik Indonesia. 